\title{
Antirealism of new reality or art against personality: with the eyes of the philosophy
}

\author{
Alla Matveeva*, Roman Krasnov, Elena Atmanskykh, and Stanislav Bannykh \\ Ural State University of Economics, 620144, Yekaterinburg, Russia
}

\begin{abstract}
In the article, the authors provide an assessment of the modernism art, cultivated for decades, in terms of the possibilities of its social and ideological influence. It is argued that the ideologists of the bourgeoisie had to admit that Western art culture was at an impasse. The article analyzes the works of philosophers and artists, such as: Lenin, Schwartz, Nietzsche, Brooke, Leist, Meyer, Reed, Bergson, Lauterbach, Huxley, Weir, etc. Among the many concepts - the theory of "cultural circles", "cultural lag" and "cultural traditions"; Theory of Art Evolution Professor Munroe; theory of social and cultural dynamics P. Sorokin and others. However, none of these theories could put forward any significant, practically effective ideas that could breathe life into bourgeois art. Summing up the results of more than half a century of the modernism art, we can say that it did not enrich the artistic culture. Starting with contrasting itself with traditional art in a philosophical, theoretical and aesthetic sense, modernism fell outside the scope of art itself due to the absurdity of its practice. The authors believe that in search of a way out of the impasse, bourgeois scholars could not escape from "anti-realism" and art was against the individual. The path traveled by modernist art proves the futility of bourgeois art culture in the first half of the twentieth century, but does not deny its revival in the XXI century.
\end{abstract}

\section{Introduction}

The art of modernism, so beloved by many modern aesthetes of the XXI century, was very controversial at the beginning of the twentieth century and was called the "art of imperialism or the bourgeoisie." V.I. Lenin was a contemporary and witness to the development of the imperialism art, at the beginning of the XX century. A supporter of everything truly innovative, revolutionary, Lenin criticized the demagogic "innovations" of the modernists, which covered up the collapse of bourgeois art (Lenin, 1969, p.663).

Otherwise, there was a fate of Western art. According to contemporaries of that time, the ideologists of the bourgeoisie did not oppose anarchy and chaos in artistic creation, for decades but they in every way encouraged any philosophical-idealistic concepts that tear art from reality and negate its social significance. The study of the art of the "bourgeoisie" is

\footnotetext{
*Corresponding author: matveevaa2011@yandex.ru
} 
now becoming the most relevant, as it allows you to look at it through the eyes of modern person.

\section{Wording of the problem}

In the article, the authors attempt to figure out why, portraying the world as chaos, as a random combination of absurd phenomena unknowable by reason, Western artists imposed on the masses a distorted image of reality, devoid of objective and knowable laws of social development and therefore not amenable to transformation. Bourgeois art was thus one of the means for diverting the masses from social activity.

\section{Research Methods}

The methodological basis of the article is the principles of integrity, objectivity and historicism. The following methods were applied: historical and philosophical analysis, focused on the objective completeness of the study; cultural and comparative approaches aimed at establishing spiritual ties between artists of different historical eras.

\section{Cases and their research}

Meeting the interests of the people, the art of socialist realism carried high aesthetic ideals to people, contributes to the improvement of our society, the harmonious development of the individual. When studying literary sources on this subject, we read everywhere that the successes of Soviet socialist culture served as an impetus for bourgeois scholars to realize the crisis state of Western art. Assessing the art of modernism, cultivated for decades, in terms of the possibilities for its social and ideological influence, the ideologists of the bourgeoisie had to admit that Western art culture was at a standstill (Mierendorf and Tost, 1957, p.9).

The state of art is recognized as completely unsatisfactory by the West German sociologist E. Schwartz. "If we consider the current state of art, then crisis phenomena break through here. As if the mirror in which the artist saw the world broke, and now between the fragments that can reflect only a fragmented picture, mental dregs are oozing. In any case, the artist does not need external "nature" - he wants to capture the value,"stated American scientist J. Brook in his book "One and Many". Bourgeois scholars now also regret the excessive "successes" of nihilism, which has been stubbornly embedded in people's minds for decades, for example, West German scientist F. Leist in the book "Existence and Nothing. The experience of analyzing nihilism "makes radical conclusions". Nietzsche wrote: "Nihilism is standing at the door. Where did this most terrible of all guests come to us from?" (Schwarz, 1960, p. 251). Add to this: it is no longer standing at the door. It entered and became human being. It begins to destroy humans and turn the earth into a desert. Having ascertained the crisis of Western art culture, some of the bourgeois scholars attempted to analyze its causes and almost unanimously came to the conclusion that the main reason for the decline of modern art is the lack of it, as in all bourgeois culture, leading generally attractive ideas.

Reflecting on the causes of the bourgeois art crisis that developed in the first quarter of our century, the French scholar Meyer writes: "The mind of human generations born after the beginning of the century is distorted by the methods of irrational judgment, understanding and vision of our era, but I cannot stop myself from believing that our youngest sons, whose upbringing has barely begun, will rise up against our own cretinism, elevated to genius, and that later they will be surprised to ask themselves if they lived in the 
world between 1900 and 1930 and some kind of mental illness" (Mayer, 1953, p.106). Many Western aesthetics are gradually revising their positions regarding the social functions of art. In this regard, the evolution of G. Reed is characteristic, until the last days of his life occupying a leading position among the aesthetics of capitalist countries. In 1960, at the IV International Aesthetic Congress, G. Reed set forth in his report "Problems of Aesthetic Consciousness" (Bergson, 1914, p. 56), a completely antisocial point of view on the goals and objectives of artistic creation: "As artists, we are only occupied with dynamics of our feelings - works are judged by the truth of feelings, and not by aesthetic the value of feelings, as such. Feelings excited by the harmony of two or three colors have more aesthetic value than sympathy for the poor. In relation to consciousness, feelings are not hierarchical: they are strong and weak, and not good or bad" (Bergson, 1914, p. 120). In subsequent years, G. Reed changed his position and expressed the opposite point of view on the place of art in society: "My erroneous idea, which I was guilty of in the past, was the idea of art as self-expression. If each artist expresses exclusively the uniqueness and peculiarity of himself, then art will be destructive and antisocial (Bergson, 1914, p. 156). In his search for ways to sociologize art, Herbert Reed turned to Marxism. However, G. Reed was "on the way" with the Marxists only until he became confronted with the need to determine the purpose of the artist in modern society. In this sensitive issue, the English aesthetic remained in the protective positions of bourgeois society.

The loss by art of "social significance" modernism led bourgeois scholars to question the value for some of the traditional foundations for bourgeois art culture, in particular individualism. "Historically, individualism is anything but world value," German scientist A. Lauterbach, working in the USA, in his book "Capitalism and Socialism from a New Point of View", emphasizes: "We cannot afford to just come to a conclusion, that a person is irrational, and calm down on this. You only need to look at the modern world in order to understand the danger of such self-abasement "Recognizing that" material success has not in any way eliminated the general atmosphere of uncertainty, but, on the contrary, has focused more on questions of the very future economic order" (Lauterbach, 1963, p. 46). A. Lauterbach concludes that "non-economic influences are becoming increasingly significant in economic decisions." In his reasoning A. Lauterbach proceeds from a fair conviction that an ideological orientation is needed in any activity, including artistic: "nihilism" requires spiritual support and spiritual orientation from "ideology" if it wants to become effective and master the worldview of the masses" (Lauterbach, 1963, p. 11). In search of a way out of the impasse, bourgeois scholars at the beginning of the XX century offered many conceptual options and theories of cultural development. Among them, one cannot fail to mention the theory of Professor Huxley cultural development, that carried out the idea of "self-action" and "self-transformation" of cultural development processes. Huxley interprets these processes as the activity result of general laws characteristic for the inorganic, organic, and psychosocial stages of the nature development. The American sociologist Caroline Ware proposed a behaviorist theory of cultural models, according to which each society is a kind of integral whole, the basic life processes and social relations of which constitute a "model of social behavior" (Kulikova, 1974, p. 135), which is embodied, in particular, in artistic activities.

In the 1950s, these obvious signs of the modernist art collapse were for the most part perceived as a "childhood illness" (Kulikova, 1974, p. 123) of the artistic culture growth. In the voluminous work Morale of the Future (Paris, 1953), French bourgeois scholar Charles Meyer writes: "Since the end of World War I, a whole school of art and literature emphasizes an absolute disregard for thoughtful and logical constructions and constructions.

Realizing the "excesses" of modernist art, S. Meyer justifies it from the point of view of socio-psychology: "Jazz, surrealism, abuse of symbols, denial of all rational objects, 
mysticism and incoherence meet the needs of a person when he tries to forget cruelty for a while twentieth century. He seeks to recreate in himself the mental state of a child, primitive or wild "(Mayer, 1953, p.107). Considering contemporary bourgeois art as a kind of psychotherapy, C. Meyer confidently predicts a fast rise in the field of the artistic life of the capitalist countries, the return of art to the path of reason.

C. Meyer's forecasts were published in the first half of the XX century, but today in the XXI century it can be said with certainty that they did not materialize: bourgeois art not only did not return "to the path of reason", but also completely went beyond art itself. The return of bourgeois artists and writers to realism did not happen and could not happen, because realism was "disadvantageous" to the bourgeoisie. The social effectiveness of realistic art made bourgeois ideologists constantly seek ways to combat it. If earlier this struggle was limited to attempts to push back realism with the help of the formalistic trends of modernist art, then over the last decade of the first half of the XX century tactics have changed: Western theorists and practitioners of art are trying to decompose realism from the inside out by falsifying the very concept of realism. These new trends are recorded by progressive cultural figures of bourgeois countries. At the forefront of the new campaign against realism were American aesthetics and art historians, who made an attempt to theoretically justify the replacement of the reflection principle with the art of reality.

The idea of the bourgeois art practice of the 1960s, of modernist art new type, known as "pop art", is given by the exhibition of works by one of the leading figures in this direction, the American Rauschenberg, held in New York in 1963. The first hall was the huge "White Picture" is exhibited - a canvas on which there was nothing but white paint. According to the author's intention, the picture itself was composed of elements outside it - the shadows of passing spectators, glare of light, etc. Rauschenberg saw the aesthetic value of the painting in its "invasion of the life art", its "direct participation in the work." According to Rauschenberg, this is precisely what the "new reality" of pop art consists of.

There were discussions at the exhibition. The audience, especially the ladies, was struck by the author's increased interest in the ugly. Rauschenberg tried to explain that the ugly as such does not exist: it all depends on how to perceive a particular phenomenon, object. Rauschenberg considers his work to be the opposite of the abstract artists' subjectivity who are trying to "express themselves" at the time of the brush's meeting with the canvas. Rauschenberg considers his works to be faceless, his emotions; taste does not participate in their creation. Rauschenberg emphasizes that the principle of "design is embodiment" is alien to him, that is, the principle of the birth in the mind of an idea and its objectification on the canvas. Rauschenberg recognizes only "pure practice." Expressing his understanding of art and artistic creation, Rauschenberg said that painting, in his opinion, belongs to both art and life. Neither one nor the other can be done. The artist, according to Rauschenberg, works "in the gap between them" (Kulikova, 1974, p. 139).

The pop art emergence in the United States coincided with a sharp drop in prices for works of abstract artists, and many began to consider it as a possible replacement for the lost popularity of abstract art. It was only necessary to skillfully "file" it on the world stage, presenting as the last achievement the most modern art. A suitable case turned up in 1964. At the next Bienale exhibition in Venice, all means were launched: not only advertising and the press, which were supposed to form public opinion, but also diplomatic influence. As a result, the first prize of the exhibition was awarded to R. Rauschenberg for a picture that presented a piece of Kennedy's photograph, a barn castle, clippings from illustrated magazines, colorful postcards and other items. This "picture" occupied an entire wall in one of the exhibition pavilions. Awarding the first prize to Rauschenberg caused a wave of indignation, but the job was done: pop art became world famous. Crafts of pop art along with the works of abstract artists and surrealists filled the halls of bourgeois museums. Pop 
art has become one of the dominant trends in contemporary modernist art. Criticism praised pop art as the highest achievement of our time.

Announcing pop art as a new trend in the art of modernism, bourgeois theorists and art historians forgot that pop art works are by no means new, viewers saw similar crafts half a century ago. It is enough to recall the notorious "fountain-urinal" of the Dadaists or "Merz" - crafts of Schwitters, who even tried to aesthetically substantiate his attempts to create "art" works from the waste of human civilization. Surrealistic "objects" are similar to pop art. Returning in his "latest achievements" to the samples of the 1920s, modernism closed the circle of its development.

Summing up the results of more than half a century of the modernism art, we can say that it did not enrich the artistic culture. Starting with contrasting itself with traditional art in a philosophical, theoretical and aesthetic sense, modernism fell outside the scope of art itself due to the absurdity of its practice. Along with pop art, other "soap bubbles" of new modernist trends appeared in bourgeois art life, which quickly disappeared without leaving any traces in art (Kulikova, 1974, p. 139).

One of such short-lived creations was the direction of the so-called p-a-mouth (optical art). Op art showed, as a rule, meaningless abstract designs that were illuminated with colored bulbs. Sometimes the colors of lighting changed, alternated, which was to symbolize the dynamics, the change in the structure itself. Formalistic delights quickly bothered the audience. The increase in the size of the works did not help either, the audience was indifferent even to the huge op-art "paintings" created with the help of a special apparatus that projected constantly changing color spots from the bell tower onto the white wall of the house.

So, in one of the museums in Amsterdam, a "mobile" is exhibited, which is a moving false jaw connected by laces. So extremely formalist modernism was completed its experiments on the transmission of movement by means of art. One of the latest inventions of modernist innovators is the so-called suicidal, or self-destructing, art (Melman, 1960, p. 45).

Then the production of works of "self-destructing" art was rationalized. The enterprising artist Yves Klein sold the audience the right to visit an empty room instead of an exhibition. He justified this commercial trick as an artistic expression of absolute emptiness. Klein's find was quickly transferred to the field of music. The pianist who entered the stage sat in front of the piano for three minutes without picking up a single note - he expressed absolute silence by means of music.

The further development of the art of modernism causes involuntary associations with the play of E. Ionesco "Amedean, or how to get rid of it" (Egorov, 1962, p. 101). One of the characters in the play is a corpse of a decade ago. This corpse, following the author's bizarre fantasy, gets sick with a specific "cadaverous" disease - it begins to grow exorbitantly. First, he crawls out of bed, then he crawls out of the room, and then, leaning against the walls of the apartment, threatens the hearth of the family that sheltered him.

Bourgeois modernist art also fell ill with such a "cadaverous" disease: his works began to grow excessively. In 1968, one of the modernist artists created the longest painting in the world. The canvas stretched for one and a half kilometers. Every hundred meters of a "masterpiece" (Egorov, 1962, p.109) is authenticated by the original signature of its creator. The artist openly shared the secret of his skill with the Daily Express correspondent: he painted every three hundred meters with a different Color. Artistic abilities were not needed, the skills of a house painter were enough. The catastrophic position of contemporary bourgeois art was noted and is noted by many progressive and simply sensible foreign critics.

A particular note at congresses is the de-professionalization of many contemporary modernist artists. "Originality, renewal efforts, searches for the sake of searches, avant- 
garde art, the art of laboratories and essays are so many words to express non-conformism that it turns into a new conformism, canceling in advance the opportunity to positively influence the development of the individuality by school, studio, conservatory. Because there cannot be true originality without a long study of oneself and one's own means, for which training serves," said French scientist J. Duron at the IV Aesthetic Congress (Jullia, 1966, p.60).

The decline of the modernism art isn't denied now by those bourgeois aesthetics and critics who recently defended it. At the last, VII International Aesthetic Congress (Bucharest, 1972), the question wasn't not discussed of the "heyday of modernism" already, but of the chances of its "survival" (Murno, 1960, p. 34). None of the participants in the congress challenged the crisis state of the modernism art. Opinions differed only on the nature and causes of this protracted crisis.

Italian aesthetics Gianno Vattimo directly linked the crisis of modernism with the conditions of the art existence in the capitalist countries: "At present, we are witnessing a crisis of art that has become the object of sale. Therefore, the position of many artists is very ironic, aggressive, this is the position of people who want to overwhelm the buyer" (ddd). The Norwegian scientist Gzhel Skilstad, who assigns responsibility for the crisis not only and not so much to artists, but to society, penetrates deeper into the essence of the problem: "In such cases: (I mean Western art) the ability of creativity is hindered by the power of capital, large monopolies, colonization. Morality, which is part of any act of artistic creation, disappears, and art ceases to be art" (Heer, 1962, p.111).

The social roots of the elite bourgeois art "dying" are revealed by the West German professor Diethart Kerbs: "The notorious" end of art "is basically nothing but the end of the collective consciousness of the bourgeois class, the collapse of which has now captured various areas of aesthetics" (Lunacharsky, 1967, p .54). But not all bourgeois aesthetics are aware of the social causes of this crisis. During the discussions at the congress, characteristic "roundabout maneuvers" were revealed, with the help of which bourgeois scholars try to obscure or justify the decadent state of modern bourgeois art. Some defenders of modernism sought to explain its decline by some "growth disease" (Melman, 1960, p. 43).

The French aesthetics R. Season proposes to replace the concept of "death of art" (a term widely used at the congress to characterize the contemporary state of the modernism art) with the idea of the natural destruction of individual forms of art that supposedly interfere with the free development of imagination. The Swiss J. Monier is trying to explain in a peculiar way the collapse of the modernism art: he considers the crisis of modernism as a consequence of "an excess of information" (Kulikova, 1974, p. 141). It is "reinformation" that, from his point of view, causes a feeling of "irresistible loneliness", which is reflected in art and literature, for example, in the "new novel".

\section{Conclusion}

In conclusion, we can summarize that in search of a way out for the impasse, bourgeois scholars in recent years in the first half of the XX century offered many cultural conceptual options and theories of cultural development, but they did not save from "anti-realism" and art was against the individual. Among them, one cannot fail to mention Hasley theory of cultural development, who pursued the idea of "self-development" and "selftransformation" (I. Kulikova, 1974, p. 145)

It is characteristic that bourgeois scholars, both those who tried to uncover the causes of the modernism crisis, and those who interpreted it as a "growth disease," did not propose concrete ways to bring bourgeois art out of its current state. However, they could not do this, remaining in the position of philosophical idealism. Deprived of ties with life, without 
progressive ideological support, the art of modernism is forced to invent new tricks to attract the attention of spectators and the press. Following pop art, a whole series of modernist trends appeared in which the pursuit of "objectivity", "materiality" of art, bypassing the method of realism, acquired the most bizarre and ridiculous forms. One of such innovations is a flock of so-called body art.

At the Bienal 1968 exhibition in Stockholm, under the guise of a work of art, a cell with a group of artists was demonstrated. The inscription read "Homo sapiens." The head of this "creative group" rented a cage with artists to any solvent audience.

However, bourgeois aesthetics announced that this kind of art work has a new kind of aesthetic value, "in a new way solving the problem of communication between the artist and the public." The shape of the sculpture is invisible, but it exists. The work carries the functions of "pure information" and is literally priceless - it cannot be sold. The most "dynamic" of the newest trends in modernist art are the so-called "happenings" (Lunacharsky, 1967, p. 67). "Happings" quite obviously went beyond the boundaries of art itself, turning into excursions to "unexpected places".

If we turn to the question for the method of creating the "newest" works for modernist art, it will not be difficult to notice that modern modernists have largely abandoned the methods of form-creation traditional for this type of art. The main method of modernists of recent times is the method of naturalism, taken to extremes. If the naturalism of art of the XIX and early XX centuries manifested in the desire to reproduce life with mirror precision, then modern modernists instead of reflecting objects and phenomena of reality by means of art give these objects and phenomena themselves as works of art. The role of the artist in the creation of such "works" is reduced to a minimum, boiling down to "organizing vital material." Starting with rebellion, with self-expression due to the rejection of the reflection of reality by means of art, the modernists have gone the way, destined for all idealists.

Among the many concepts - the theory of "cultural circles", "cultural lag" and "cultural traditions"; Theory of Art Evolution - Professor Munroe; theory of social and cultural dynamics P. Sorokin and others. However, none of these theories could put forward any significant, practically effective ideas that could breathe life into bourgeois art. The path traveled by modernist art proves the futility of bourgeois art culture in the first half of the twentieth century, but does not deny its revival in the XXI century.

\section{References}

1. A. Lauterbach, Kpitalismus und Sozialismus in neure Sicht (Reinbeck, 1963).

2. Ch. Mayer, La Morale de l "avenir, (Paris, 1953).

3. E. Schwarz, Am Wendepunkt. Weltbild und Mensch Atomzeitalter (Stuttgart, 1960).

4. F. Heer, Offener Humanismus (Berlin - Stuttgart - Wien, 1962).

5. R. Jullia, Le futurism et la peinture italienne (Paris, 1966).

6. S. Melman, The Peace Rase (London, 1960).

7. Th. Murno, The Marxist Theory of Art History. Socio-economic Determinism and Dialectical Process, The Journal of Aesthetics and Art Criticism, 4, (1960).

8. A. Bergson, Creative evolution (M. - St. Petersburg, 1914).

9. A. Egorov, About the reactionary essence of modern bourgeois aesthetics (Moscow, 1962).

10. A.V. Lunacharsky, Art and its latest forms (Sobr. Op. in eight volumes, vol. 7, Moscow, 1967). 
11. V.I. Lenin, V.I. Lenin about literature and art (Moscow, 1969).

12. I. Kulikova, The philosophy and art of modernism (Politizdat, Moscow, 1974).

13. M. Mierendorf, H. Tost, Einfhrung in die Kunstsoziologie (Keln, 1957). 